\title{
PERIODONTAL CONDITIONS OF ELDERS IN NORTHEASTERN BRAZIL
}

\section{Condições periodontais de idosos do Nordeste do Brasil}

Condiciones periodontal de mayores del Noreste de Brasil

Artigo Original

\begin{abstract}
Objective: To evaluate the periodontal conditions of elderly patients assisted in a Specialized Dentistry Center in Northeastern of Brazil. Methods: Quantitative and cross-sectional study conducted with 152 elders. It was used a questionnaire to get information about socio-demographic aspects (age, sex, gender, income, and education), general healthand periodontal clinical examination based on the Communitarian Periodontal Index (CPI), an indicator recommended by the World Health Organization (WHO), who enabled the evaluation of the periodontal condition. It was used Pearson's Chi-square Distribution, or Fisher's Exact Test, with significance level tests 5\%. Results: The elders age ranged from 60 to 89 years, mean of 67.6 years $(\mathrm{SD} \pm 6.13)$. The variables female $70(53.9 \%)$, retiree $95(62.5 \%)$, low income $91(59.0 \%)$, secondary school $60(39.5 \%)$ predominated and 130 $(85.5 \%)$ elders used medicines. Most evidenced self-reported diseases: eye problems 123 (80.9\%), cardiovascular disorders $107(70.4 \%)$, osteoporosis $77(50.7 \%)$ and diabetes 54 (35.5\%). Dental calculus prevailed $128(84.2 \%)$. Statistical significance was found between the presence ofperiodontal pocket and age group 60-65 years $(p=0.027)$; dental calculus andbrushing teeth once a day $(\mathrm{p}=0.028)$; not use of dental floss and periodontal pocket from 4 to $5 \mathrm{~mm}(\mathrm{p}=0.001)$; use of toothpick with periodontal pocket from 4 to $5 \mathrm{~mm}(0.018)$ and of $6 \mathrm{~mm}$ or more $(\mathrm{p}=0.001)$; educational level and dental calculus $(\mathrm{p}=0.005)$. Conclusion: The periodontal health of this population is covered with precariousness, mainly due to dental calculus and periodontal pocket.
\end{abstract}

Descriptors: Aging; Elderly; Periodontics; Oral Health.

\section{RESUMO}

Objetivo: Avaliar a condição periodontal de pacientes idosos atendidos em um Centro Especializado de Odontologia, no Nordeste do Brasil. Métodos: Estudo quantitativo, transversal e analitico, realizado com 152 idosos, no qual se utilizou um questionário referente a dados sociodemográficos (idade, sexo, renda, nível educacional) e saúde geral, e exame clínico periodontal baseado no Índice Periodontal Comunitário (CPI), um indicador recomendado pela Organização Mundial da Saúde que permite avaliar a condição de saúde periodontal. Resultados: A idade dos idosos variou de 60 a 89 anos, média de 67,6 anos $(D P \pm 6,13)$. Predominou gênero feminino (70 - 53,9\%), raça branca $(81-53,3 \%)$, aposentados (95 - 62,5\%), baixa renda (91 - 59,0\%) e nível educacional até o primeiro grau completo (60 - 39,5\%). Sobre percepção da saúde, 109 idosos (71,7\%) consideraram-na razoável, e para 143 (94,1\%), ela permaneceu igual ao último ano. Foram detectados 130 $(85,5 \%)$ idosos tomando medicamento. Doenças autorreferidas evidenciadas: problemas de visão (123 - 80,9\%), distúrbios cardiovasculares (107 - 70,4\%), osteoporose (77 - 50,7\%) e diabetes (54 - 35,5\%). O cálculo dentário apresentou-se prevalente (128 - 84,2\%). Houve significância estatística entre presença de bolsa periodontal e faixa etária de 60 a 65 anos $(p=0,027)$; calculo dentário e escovar os dentes uma vez ao dia ( $p=0,028)$; não uso do fio dental e bolsa periodontal de 4 a $5 \mathrm{~mm}(p=0,001)$; utilizar palito e bolsa periodontal de 4 a $5 \mathrm{~mm}(p=0,018)$ e de $6 \mathrm{~mm}$ ou mais ( $p=0,001)$; escolaridade e cálculo dentário $(p=0,005)$; depressão e cálculo dentário ( $p=0,007)$; depressão e bolsa periodontal de $6 \mathrm{~mm}$ ou mais $(p=0,039)$. Conclusão. A saúde periodontal dessa população reveste-se de precariedade, sobretudo em razão de cálculo dentário e bolsa periodontal.

Descritores: Envelhecimento; Idoso; Periodontia; Saúde bucal.

\section{Maria Vieira de Lima Saintrain ${ }^{(1)}$ Maria Daucirlene Costa Aquino ${ }^{(2)}$}

1) Universidade de Fortaleza - UNIFOR Fortaleza (CE) Brasil

2) Secretaria de Saúde do Estado do Ceará SESA - Fortaleza (CE) Brasil
Recebido em: 25/05/2013

Revisado em: 24/01/2014 Aceito em: 24/09/2014 


\section{RESUMEN}

Objetivo: Evaluar la condición periodontal de pacientes mayores asistidos en un Centro Especializado en Odontología del Noreste de Brasil. Métodos: Estudio cuantitativo, transversal y analítico con 152 mayores en el cual se utilizó un cuestionario sobre datos sociodemográficos (edad, sexo, renta, nivel educacional) y salud general, y el examen clínico periodontal basado en el Índice Periodontal Comunitario (IPC), un indicador recomendado por la Organización Mundial de la Salud que permite evaluar la condición de salud periodontal. Resultados: La edad de los mayores varió de 60 a 89 años con media de 67,6 años $(S D \pm 6,13)$. Hubo predominio del género femenino (70 - 53,9\%), raza blanca (81-53,3\%), jubilados (95 - 62,5\%), baja renta $(91-59,0 \%)$ y nivel educacional hasta la enseñanza primaria completa (60 $39,5 \%)$. Respecto la percepción de salud, 109 mayores $(71,7 \%)$ la consideraron razonable y para 143 (94,1\%), la salud permaneció igual al último año. Fueron identificados 130 (85,5\%) mayores en uso de medicamento. Enfermedades auto-referidas evidenciadas. problemas de visión (123 - 80,9\%), disturbios cardiovasculares (107 - 70,4\%), osteoporosis (77 - 50,7\%) y diabetes (54 - 35,5\%). El cálculo dental fue prevalente (128-84,2\%). Hubo significancia estadística en la presencia de bolsa periodontal y la franja de edad de 60 y 65 años $(p=0,027)$; cálculo dental y cepillar los dientes una vez al día ( $p=0,028)$; la no utilización de hilo dental y bolsa periodontal de 4 a $5 \mathrm{~mm}$ ( $p=0,001)$; la utilización de palillo y bolsa periodontal de 4 a $5 \mathrm{~mm}(p=0,018)$ y de $6 \mathrm{~mm}$ o más $(p=0,001)$; escolaridad y cálculo dental $(p=0,005)$; depresión y cálculo dental $(p=0,007)$; depresión y bolsa periodontal de $6 \mathrm{~mm}$ $o$ más ( $p=0,039)$. Conclusión: La salud periodontal de esta población es precaria, sobre todo debido al cálculo dental y bolsa periodontal.

Descriptores: Envejecimiento; Anciano; Periodoncia; salud bucal.

\section{INTRODUCTION}

Brazil, like other Latin America countries, is going through a fast demographic transition due to the decreased mortality and fertility rates and increased life expectancy, which has increased the demand for health services by the elderly ${ }^{(1)}$. Given that, there is a need for social policies that should prepare society for this reality ${ }^{(2)}$. Public services are not prepared to meet this demand and dental care is nearly excluded from oral health programs ${ }^{(3)}$

The role of Dentistry regarding the elderly population is to keep a good oral health that will not affect normal nutrition or have negative repercussions over general health and psychological state ${ }^{(4)}$. Besides caries, the periodontal disease, which is considered an infectious and contagious disease, is a public health problem worldwide. Within this context, the global goals for oral health 2020 were established to reduce periodontal diseases, tooth loss, the prevalence of necrotising forms of periodontal diseases and the active periodontal infection, as well as to increase the rate of people with healthy periodontium ${ }^{(5)}$.

Although some countries have introduced oral health promotion activities, there are few population-oriented preventive or curative activities currently implemented that focus specifically on the elderly ${ }^{(6)}$.

In 2002, it was conducted the amplest and most complete national research - the Project "SB Brazil - Oral health conditions of the Brazilian population". It was the first national survey that included people aged 60 years and over in the study population. In all, 5349 people aged 65-74 years old from 250 municipalities throughout the country were included ${ }^{(7)}$.The most important results obtained from this survey for the age group 65-74 years were: high prevalence of caries (considering that $99.5 \%$ of the interviewees had at least one tooth with caries); only 7.9\% of the people did not have any periodontal problems; $32.0 \%$ of the elders needed upper prosthesis and $56.0 \%$ needed lower prosthesis. Regarding the access to oral health care, $65.7 \%$ of the interviewees have not been to the dentist for over a 3-year period and 5.8\% had never received dental care. Within this percentage of elders, $40.5 \%$ reported using the public service while $40.3 \%$ used the private service ${ }^{(7)}$.

In 2010, a new national epidemiological survey, SB BRAZIL - 2010, was conducted using the same methodology established by the WHO. This research detected few improvements in the oral health of the elderly and observed that of all the people in the age group 65-74 years only $1.8 \%$ did not have periodontal disease and only $28.9 \%$ used the public service. It was also observed that the gingival problems in elders are not so expressive given the reduced number of teeth ${ }^{(8)}$.

The caries disease is fully studied while the tooth loss is one of the most visible results of the physiological evolution caused by periodontal disease ${ }^{(9)}$.

With the population ageing, the problem of health demands greater attention ${ }^{(1)}$. Within this context, this study aimed to assess the periodontal conditions of elderly patients assisted in a Specialized Dentistry Center in Northeastern Brazil.

\section{METHODS}

An observational, cross-sectional, quantitative and analytic study was conducted with elderly people aged 60 years and over assisted in the Centro de Especialidades Odontológicas - CEO Centro (Specialized Dentistry Center located downtown) of Fortaleza, capital of Ceará-Brazil. It was considered elderly the individuals aged 60 years and over, according to the Elderly People National Health Policy ${ }^{(10)}$. 
The CEO Centro is a public institution that works as a dental care reference for the state health system in Ceará, Northeastern Brazil. People who seek care in the center come from the capital and all around the state insured by public institutions or private clinics.

Considering the number of 414 elders (quarterly average of elders who attend CEO Centro), the sample size was determined $(\mathrm{n}=152)$ with a margin of safety of $95 \%$ and sampling error of $6.3 \%$.

Data were obtained through: a) a questionnaire with closed-ended questions about socio-demographic aspects (age, gender, income, and education), use of medicines and self-reported general health; b) a periodontal clinical examination performed by the researcher, who is a dentistsurgeon, and an oral health assistant, who took notes.

The Community Periodontal Index (CPI), an indicator recommended by the World Health Organization (WHO), was used for the clinical examination. It enabled the assessment of the periodontal condition regarding healthiness, bleeding, presence of calculus and periodontal pocket $^{(11)}$.

Patients were contacted in the CEO Centro from Monday to Friday during the morning, from April to June 2010. They were informed about the objectives of the research. Those who agreed to participate signed a free informed consent form prior to the study, answered the questionnaire, and then underwent the periodontal clinical examination.

People who were under 60 years old and edentulous elders were excluded from the study.

The examinations were carried out in an office of the CEO under artificial light, using a flat mouth mirror and periodontal probe recommended by the WHO. The periodontal probe is characterized by having a sphere of 0.5 $\mathrm{mm}$ at its tip and a ringed area in black located between 3.5 $\mathrm{mm}$ and $5.5 \mathrm{~mm}$ from the tip, with two other markers that can indicate distances of $8.5 \mathrm{~mm}$ and $11.5 \mathrm{~mm}$ from the tip of the instrument ${ }^{(11)}$

The procedures for the periodontal clinical examination considered the division of the mouth in sextants defined by the teeth: 18-14, 13-23, 24-28, 38-34, 33-43 and 44-48. Index teeth for each sextant are: 17 and 16 ( $1^{\text {st }}$ sextant $) ; 11$ ( $2^{\text {nd }}$ sextant $) ; 26$ and 27 ( $3^{\text {rd }}$ sextant $) ; 37$ and 36 ( $4^{\text {th }}$ sextant $)$; $31\left(5^{\text {th }}\right.$ sextant $) ; 46$ and 47 ( $6^{\text {th }}$ sextant $)$. If any of the index teeth were not present, all the remaining teeth of the sextant would be examined without considering the distal surface and third molars. A sextant must be examined only if there are two or more teeth that shall not have an indication for exodontia.

Researchers examined six points in each of the indexteeth in the buccal and lingual surfaces, comprehending the mesial, middle and distal regions. They started the examinations from the distobuccal area, going through the middle area and then to the mesiobuccal. Then, they inspected the lingual areas from the distal to the mesial regions. The probe, slightly tilted along the axis of the tooth, was lightly introduced in the gingival sulcus or in the periodontal pocket, according to the anatomic configuration of the root surface. The strength in the probing was inferior to 20 grams, that is, the strength coming from the testing of the thumbnail pressed to obtain slightly ischemia, as it is recommended by the $\mathrm{WHO}^{(11)}$.

Six registrations were made, one for each sextant, indicating the highest rate in the appropriate field using the codes: 0 - healthy sextant; 1 - sextant with bleeding (observed with a mirror or directly after probing); 2- calculus (any quantity, but with the whole black area of the probe visible); 3 - pocket from 4 to $5 \mathrm{~mm}$ (gingival margin in the black area of the probe); 4- pocket of $6 \mathrm{~mm}$ or more (black area of the probe is not visible); $\mathrm{X}$ - excluded sextant (less than two teeth); 9- non-examined sextant (lack of teeth).

The software Statistical Package for the Social Sciences 17.0 (SPSS Inc., Chicago, IL, USA) was used in data analysis. It was used Pearson's Chi-square Distribution, or Fisher's Exact Test when the conditions to employ the Chisquare Distribution were not verified. The significance level of the statistical tests was set at $5 \%(\mathrm{p} \leq 0.05)$.

Without any conflicts of interest, the Project was approved by the Research Ethics Committee of the Dentistry Academy of Ceará under number 106/2009.

\section{RESULTS}

In all, 152 elderly patients aged 60-89 years, mean of 67.6 years $( \pm 6.13)$, participated in the research. The most prevalent variables were: age group $60-65$ years $(44.7 \%)$, women $70(53.9 \%)$, retiree $95(62.5 \%)$, low income - less than a minimum wage $-91(59.0 \%)$ and primary school education $60(39.5 \%)$. It was observed that $130(85.5 \%)$ elders used medicines, and of these, 83 (63.9\%) used from two to three different types.

The most evidenced self-reported diseases were: eye problems $123(80.9 \%)$, cardiovascular disorders 107 (70.4\%), osteoporosis 77 (50.7\%) and diabetes 54 (35.5\%).

According to the categories of the CPI, the presence of calculus was the most prevalent circumstance $128(84.2 \%)$, followed by the presence of periodontal pocket from 4 to $5 \mathrm{~mm} 55(36.2 \%)$, gingival bleeding $46(30.3 \%)$ and periodontal pocket of $6 \mathrm{~mm}$ or more $40(26.3 \%)$.

Statistical significance was found between the presence of periodontal pocket and age group 60-65 years $(\mathrm{p}=0.027)$; educational level and dental calculus $(\mathrm{p}=0.005)$; dental 
Table I - Periodontal condition of sextants in elders according to age group. Fortaleza-CE, 2010.

\begin{tabular}{lccccc}
\hline \multirow{2}{*}{ Age group } & \multicolumn{5}{c}{ Periodontal condition } \\
\cline { 2 - 6 } & Bleeding & Calculus & $\begin{array}{c}\text { Periodontal } \\
\text { pocket4 to 5 mm }\end{array}$ & $\begin{array}{c}\text { Periodontal pocket } \\
\text { 6 mm or more }\end{array}$ & Total \\
\hline 60 to 65 years & $19(12.5 \%)$ & $61(40.1 \%)$ & $31(20.4 \%)$ & $21(13.8 \%)$ & $68(44.7 \%)$ \\
66 to 70 years & $17(11.2 \%)$ & $28(18.4 \%)$ & $08(5.3 \%)$ & $12(7.9 \%)$ & $37(24.3 \%)$ \\
71 to 75 years & $07(4.6 \%)$ & $27(17.8 \%)$ & $13(8.6 \%)$ & $05(3.3 \%)$ & $30(19.7 \%)$ \\
Over 75 years & $03(2.0 \%)$ & $12(7.9 \%)$ & $03(2.0 \%)$ & $02(1.3 \%)$ & $17(11.2 \%)$ \\
\hline p-value ${ }^{(1)}$ & 0.092 & 0.082 & 0.027 & 0.192 & - \\
\hline Total & $46(30.3 \%)$ & $128(84.2 \%)$ & $55(36.2 \%)$ & $40(26.3 \%)$ & $152(100 \%)$ \\
\hline
\end{tabular}

(1) Chi-square distribution

calculus and brushing teeth once a day $(\mathrm{p}=0.028)$; not using dental floss and periodontal pocket from 4 to $5 \mathrm{~mm}$ $(\mathrm{p}=0.001)$; use of toothpick and periodontal pocket from 4 to $5 \mathrm{~mm}(0.018)$ and $6 \mathrm{~mm}$ or more $(\mathrm{p}=0.001)$.

No statistical association was found between the periodontal condition and self-reported diseases or smoking.

Table I highlights the periodontal condition that is statistically significant between the presence of periodontal pocket from 4 to $5 \mathrm{~mm}$ and elders in the age group 60-65 years.
Table II shows the significant association between being at a dentist more than one year ago and presence of pocket from 4 to $5 \mathrm{~mm}$, presence of calculus and brushing the teeth once a day, no use of tooth floss and pocket from 4 to $5 \mathrm{~mm}$ and use of toothpick related to the presence of pocket from 4 to $5 \mathrm{~mm}$ and $6 \mathrm{~mm}$ or more.

Table III shows that the $5^{\text {th }}$ sextant showed higher prevalence of dental calculus $112(73.7 \%)$ and low occurrence of periodontal pocket $02(1.3 \%)$ as well as it was not excluded in any of the elderly. Calculus and periodontal

Table II - Periodontal condition of sextants in elders according dental care. Fortaleza-CE, 2010.

\begin{tabular}{|c|c|c|c|c|}
\hline \multirow[b]{2}{*}{ Care } & \multicolumn{4}{|c|}{ Periodontal condition } \\
\hline & Bleeding & Calculus & $\begin{array}{c}\text { Pocket from } 4 \text { to } \\
5 \mathrm{~mm}\end{array}$ & $\begin{array}{c}\text { Pocket of } 6 \mathrm{~mm} \text { or } \\
\text { more }\end{array}$ \\
\hline \multicolumn{5}{|c|}{ When was your last visit to the dentist } \\
\hline 6 months & $06(3.9 \%)$ & $17(11.2 \%)$ & $11(7.2 \%)$ & $06(3.9 \%)$ \\
\hline 1year & $12(7.9 \%)$ & $30(19.7 \%)$ & $15(9.9 \%)$ & $14(9.2 \%)$ \\
\hline More than1year & $28(18.4 \%)$ & $81(53.3 \%)$ & $29(19.1 \%)$ & $20(13.2 \%)$ \\
\hline p-value & $0.875^{1}$ & $0.797^{2}$ & $0.050^{l}$ & $0.089^{1}$ \\
\hline \multicolumn{5}{|c|}{ Number of times you brush the teeth per day } \\
\hline 1 time & $23(15.1 \%)$ & $59(38.8 \%)$ & $24(15.8 \%)$ & $18(11.8 \%)$ \\
\hline 2 times & $15(9.9 \%)$ & $45(29.6 \%)$ & $18(11.8 \%)$ & $14(9.2 \%)$ \\
\hline 3 times & $08(5.3 \%)$ & $24(15.8 \%)$ & $13(8.6 \%)$ & $08(5.3 \%)$ \\
\hline $\mathrm{p}$-value & $0.925^{1}$ & $0.028^{2}$ & $0.128^{1}$ & $0.641^{1}$ \\
\hline \multicolumn{5}{|l|}{ Uses tooth floss } \\
\hline Yes & $08(5.3 \%)$ & $29(19.1 \%)$ & $20(13.2 \%)$ & $09(5.9 \%)$ \\
\hline No & $38(25.0 \%)$ & $99(65.1 \%)$ & $35(23.0 \%)$ & $31(20.4 \%)$ \\
\hline $\mathrm{p}$-value & $0.466^{1}$ & $0.263^{1}$ & $<0.001^{1}$ & $0.794^{1}$ \\
\hline \multicolumn{5}{|c|}{ Uses toothpick for oral hygiene } \\
\hline Yes & $35(23.0 \%)$ & $107(70.4 \%)$ & $50(32.9 \%)$ & $39(25.7 \%)$ \\
\hline No & $11(7.2 \%)$ & $21(13.8 \%)$ & $05(3.3 \%)$ & $01(0.7 \%)$ \\
\hline $\mathrm{p}$-value & $0.318^{1}$ & $0.085^{2}$ & $0.018^{1}$ & $0.001^{2}$ \\
\hline
\end{tabular}

(1) Chi-square distribution

(2) Fisher's Exact Test. 
Table III - Distribution of frequency of 152 elders in relation to Community Periodontal Index (CPI). Fortaleza-CE, 2010.

\begin{tabular}{lcccccc}
\hline \multirow{2}{*}{ CPI } & \multicolumn{7}{c}{ Sextants } \\
\cline { 2 - 7 } & $\mathbf{1 7 - 1 6}$ & $\mathbf{1 1}$ & $\mathbf{2 6 - 2 7}$ & $\mathbf{3 6 - 3 7}$ & $\mathbf{3 1}$ & $\mathbf{4 7 - 4 6}$ \\
\hline Healthy & - & $60(39.5 \%)$ & $01(0.7 \%)$ & $01(0.7 \%)$ & $12(7.9 \%)$ & $02(1.3 \%)$ \\
Bleeding & $01(0.7 \%)$ & $24(15.8 \%)$ & $01(0.7 \%)$ & $01(0.7 \%)$ & $22(14.5 \%)$ & $01(0.7 \%)$ \\
Calculus & $21(13.8 \%)$ & - & $30(1.7 \%)$ & $16(10.5 \%)$ & $112(73.7 \%)$ & $16(10.5 \%)$ \\
Pocket 4,5mm & $19(12.5 \%$ & $02(1.3 \%)$ & $17(1.2 \%)$ & $25(16.4 \%)$ & $02(1.3 \%)$ & $21(13.8 \%)$ \\
Pocket +6mm & $20(13.2 \%)$ & - & $25(1.4 \%)$ & $06(3.9 \%)$ & - & $7(4.6 \%)$ \\
Excluded sextant & $16(10.5 \%)$ & $01(0.7 \%)$ & $08(5.3 \%)$ & $30(19.7 \%)$ & - & $26(17.1 \%)$ \\
Non-examined sextant & $75(49.3 \%)$ & $65(42.8 \%)$ & $70(46.1 \%)$ & $73(48.0 \%)$ & $04(2.6 \%)$ & $79(52.0 \%)$ \\
Total & $\mathbf{1 5 2 ( 1 0 0 \% )}$ & $\mathbf{1 5 2 ( 1 0 0 \% )}$ & $\mathbf{1 5 2 ( 1 0 0 \% )}$ & $\mathbf{1 5 2 ( 1 0 0 \% )}$ & $\mathbf{1 5 2 ( 1 0 0 \% )}$ & $\mathbf{1 5 2}(\mathbf{1 0 0 \%})$ \\
\hline
\end{tabular}

Table IV - Distribution of sextants ( $\mathrm{n}=152$ elderly) regarding the presence of periodontal disease. Fortaleza-CE, 2010.

\begin{tabular}{lcc}
\hline \multirow{2}{*}{ Sextant } & \multicolumn{2}{c}{ Periodontal Disease } \\
\cline { 2 - 3 } & Yes / \% & No / \% \\
\hline $17 / 16\left(1^{\text {st }}\right)$ & $61(40.1 \%)$ & $91(59.9 \%)$ \\
$11\left(2^{\text {nd }}\right)$ & $26(17.1 \%)$ & $126(82.9 \%)$ \\
$26 / 27\left(3^{\text {rd }}\right)$ & $73(48.0 \%)$ & $79(52.0 \%)$ \\
$36 / 37\left(4^{\text {th }}\right)$ & $48(31.6 \%)$ & $104(68.4 \%)$ \\
$31\left(5^{\text {th }}\right)$ & $136(89.5 \%)$ & $16(10.5 \%)$ \\
$47 / 46\left(6^{\text {th }}\right)$ & $45(29.6 \%)$ & $107(70.4 \%)$ \\
\hline
\end{tabular}

pocket of more than $6 \mathrm{~mm}$ were not found in the $2^{\text {nd }}$ sextant, and also the $1^{\text {st }}$ sextant was not healthy in none of the elderly.

Table IV shows that the $5^{\text {th }}$ sextant was the most affected by the periodontal disease $136(89.5 \%)$ and the $2^{\text {nd }}$ sextant was the one that showed the best condition $26(17.1 \%)$.

\section{DISCUSSION}

The presence of periodontal disease associated with low educational level is corroborated by several studies ${ }^{(12,13)}$. Therefore, education has an impact on health and if attention is not drawn to education, any attempt to improve public health will be affected ${ }^{(13)}$.

No significant association was found regarding periodontal disease and elders' self-reported diseases. Regarding the cardiovascular disease, the precarious periodontal condition evidenced by sextants with gingival bleeding, dental calculus, as well as periodontal pockets is worrisome. It is considered that oral infectious processes can be implied in the inflammatory process and have an influence on the precipitation of acute coronary events; additionally, both diseases have complicated pathogeneses and clinical manifestations due to immune-system triggered inflammation $^{(14)}$. Concerning this, a research ${ }^{(15)}$ has found an association between PD and Coronary Artery Disease.
A total of $35.5 \%$ of the elders assessed in the present research reported having diabetes. It is not a surprising datum as Diabetes Mellitus is considered a global disease by the World Health Organization and by the International Diabetes Federation, afflicting 194 million people worldwide. In Brazil, 7.6\% of the population aged 30-69 years is affected by this systemic disease ${ }^{(16)}$. Although no significant association was found between periodontal disease and diabetes in the current study, researchers ${ }^{(17,18)}$ evidenced a bidirectional association between the two diseases, i.e., diabetes favors the appearance of the PD Periodontal disease and this one, when it is not treated, worsens the metabolic control of the diabetes. Besides this, the PD has a higher prevalence and seriousness in diabetic people when compared to the non-diabetic individuals ${ }^{(15)}$.

There was a high number of elderly people with PD and osteoporosis (50.7\%) in the present research; however, there was no relationship between the two diseases. A research points out the osteoporosis as a risk factor for $\mathrm{PD}$, or, at least, a factor that can increase the severity of preexisting diseases ${ }^{(19)}$. A review ${ }^{(20)}$ conducted to verify the relationship between osteoporosis and PD revealed that 11 out of the 17 studies reviewed presented a positive relationship between osteoporosis and periodontal disease. The author ${ }^{(20)}$ concludes that the data indicate a greater propensity to 
lose alveolar bone in subjects with osteoporosis, especially in subjects with preexisting periodontitis, suggesting that osteoporosis should be considered a risk factor for periodontal disease progression.

Regarding the use of medicines, it has been verified by the present study that most of the elderly used between two and three different types of medicines and presented PD in its several clinical manifestations [bleeding, calculus and periodontal pocket]. These facts are corroborated by the literature, which shows that elderly people have more problems than the adult population due to the excessive medicine intake, causing higher rates of side effects and drug interaction ${ }^{(4,21)}$; it also shows that medicine intake by the elderly alters their metabolism and may affect both the teeth and the periodontium ${ }^{(4,22)}$.

No statistical association was found between periodontal condition and smoking in the present study. However, a bibliographic research shows that smoking is considered the major risk factor in the prevalence, extent and severity of periodontal diseases and an important factor for its onset and progression ${ }^{(23)}$. Additionally, it increases the salivary flow rate and when associated to a bad oral hygiene, it facilitates the accumulation of bigger quantities of calculus ${ }^{(24)}$.

Dental calculus and periodontal pocket from 4 to 5 $\mathrm{mm}$, the most evidenced condition in the elderly assessed by the current research, are legitimated by the results of a research ${ }^{(12)}$ that has verified the presence of calculus as the main alteration in the periodontal health, followed by deep periodontal pockets and gingival retraction. In the SB Brazil 2003 and 2010, the dental calculus was also the most prevalent condition verified in the age group 65-74 years ${ }^{(7,8)}$.

Regarding oral health care, periodontal problems related to oral hygiene, mainly in the elderly who brush the teeth once a day and in those who did not use dental floss, have been observed in the current research. Corroborating these findings, another research ${ }^{(25)}$ has verified that the oral hygiene of dentulous elders was precarious. According to the authors, the idea that tooth loss is a natural consequence of ageing can lead the elderly to neglect oral hygiene measures. Moreover, the disability, lack of motivation and skills to perform certain tasks are obstacles for the elderly to perform an efficient and adequate oral hygiene. Besides this, the elderly tend to present a lowering of visual acuity, sense of touch and cognitive decline, contributing to a higher accumulation of dental plaque ${ }^{(26)}$, which leads to periodontal problems. The advanced age is not certain to cause PD; however, a bad oral hygiene is ${ }^{(27)}$. Authors are unanimous to assure that the oral hygiene is the most important measure for the maintenance of the periodontal health and that the mechanical cleaning using the toothbrush and other interproximal means is the main way to prevent periodontal diseases ${ }^{(22,28)}$

The significant association between periodontal pocket from 4 to $5 \mathrm{~mm}$ and of $6 \mathrm{~mm}$ or more and the use of toothpick found in the present study are corroborated by a research ${ }^{(29)}$ that has observed that removing food residues from the teeth with wood pick or any other kind of objects can result in inflammation, pain and discomforts. Local factors like irritation and occlusal trauma are also suggested as etiologic agents of the periodontal disease and a study proves that a bad oral hygiene associated to the non-use of dental floss can explain the increase in the number of excluded sextants with ageing ${ }^{(22)}$.

The results of the present study revealed a high prevalence of gingival calculus in the analysis of the periodontal conditions of the elderly who have not been to the dentist for more than a year. Additionally, statistical association was found between brushing the teeth once a day, not using dental floss and using toothpick with presence of periodontal pocket. Studies prove that the number of visits to the doctor increases while the number of visits to the dentist decreases with ageing and dental services are mainly sought because of pain ${ }^{(3,30)}$. In the results of SB Brazil 2003, 65.7\% of the elders have not been to the dentist for over a 3-year period ${ }^{(7)}$. However, in SB Brazil 2010 this percentage was lower (42.3\%), showing some improvements in the access to the dentist-surgeon ${ }^{(8)}$. This fact may occur mainly because of the difficulties to commute and the difficult access to these professionals, discouraging attitudes by caretakers and family members. It also occurs due to the high prevalence of natural tooth loss among Brazilian elderly people ${ }^{(30)}$.

The big quantity of non-examined sextants displayed by Table 3 is corroborated by the results of SB Brazil $2003^{(7)}$, and SB Brazil $2010^{(8)}$, in which more than $80 \%$ and $90.5 \%$ of the sextants, respectively, showed no teeth or only one functional tooth. Researchers highlight that $80.8 \%$ and $73.0 \%$ of the participants in their studies showed a reduction in the number of evaluable sextants ${ }^{(12,22)}$, which explains the low prevalence of severe PD within these age groups.

Despite the advances implemented by the national oral health policy ("Smiling Brazil Program"), the Ministry of Health encouraged the deployment of more than 15,000 oral health teams over the period from 2002 to 2010. In the same period, 72 million oral health kits were distributed, aiming to expand the access to toothbrush and fluoride toothpaste, reinforcing the fight against caries and periodontal diseases $^{(31)}$. However, considering the findings of the current research and the results of the two national surveys, it is possible to verify that the periodontal condition of the Brazilian elders is still precarious and far from meeting the international goals established. 
This problem may be explained by the need for accumulated treatment, in which patients prefer tooth extraction rather than conservative treatments ${ }^{(4,9)}$ (in this case, extracting becomes the easiest way to alleviate pain permanently) $)^{(12)}$. This condition can be associated to the lack of preventive actions and Health Education, which are insufficient in the public policies targeted to this population.

The findings of the present research show that despite the fact that most of the patients have periodontal disease in the $5^{\text {th }}$ sextant, this sextant showed the lowest exclusion rate. Similar fact was observed by authors who explain that this may occur due to the presence of the ducts of salivary glands in this region, which provides a better irrigation, favoring the mechanical cleaning and the maintenance of the teeth in this sextant for a longer time $e^{(22,25)}$.

It is important to focus on the fact that although a small sample represents a limitation for this study, it did not invalidate the findings that showed that PD is still severely present in elders despite the advances in Dentistry. Additionally, it is still a severe public health problem. Furthermore, it was possible to provide indicators for the conduction of further studies and also provide subside for the improvement of preventive and curative actions of Health Education and Promotion.

Considering that variables such as poor brushing, the lack of access to the dentist and preventive health education can influence the periodontal health condition, it is of utmost importance that the elder's healthcare policies along with the dentist-surgeon's performance should be more effective in order to meet the needs of the elderly population.

\section{CONCLUSION}

The periodontal health in the elderly population investigated is covered with precariousness due to the presence of gingival bleeding, dental calculus and the high prevalence of periodontal pocket in most of the sextants that could be examined. The gingival bleeding, the presence of dental calculus and the prevalence of periodontal pocket reveal a lack of oral hygiene care.

The great number of non-examined sextants shows the severity of edentulism, which somehow hides the real condition of the periodontal disease in Brazilian elders.

\section{REFERENCES}

1. Veras R. Terceira idade: gestão contemporânea em saúde. Rio de Janeiro: Relume Dumara; 2008

2. Veras R. Envelhecimento populacional contemporâneo: demandas, desafios e inovações. Rev Saúde Pública. 2009;43(3):1-7.
3. Tinós AMFG, Sales-Peres SHC, Rodrigues LCR. Acesso da população idosa aos serviços de saúde bucal: uma revisão. RFO UPF. 2013;18(3):351-60.

4. Rosa LB, Zuccolotto MCC, Bataglion C, Coronatto EAS. Odontogeriatria - a saúde bucal na terceira idade. RFO UPF. 2008;13(2):82-6.

5. Hobdell M, Petersen PE, Clarkson J, Johnson N. Global goals for oral health 2020. Int Dent J. 2003;53:285-8.

6. Petersen PE, D. Kandelman, Arpin DS, Ogawa H. Global oral health of older people: call for public health action. Community Dent Health. 2010;27(4 Suppl 2):257-68.

7. Ministério da Saúde (BR). Projeto SB Brasil 2003: condições de saúde bucal da população. Brasília: Ministério da Saúde; 2004.

8. Ministério da Saúde(BR). SB Brasil: Pesquisa Nacional de Saúde Bucal 2010 [Internet]. Brasília: Ministério da Saúde; 2010 [cited 2012 Feb 11]. Available from: http://dab.saude.gov.br/CNSB/sbbrasil/arquivos/ apresentacao_abbrasil_2010.pdf

9. Costa FO, Susin C, Cortelli JR, Isabela Almeida Pordeus IA. Epidemiology of periodontal disease. Int J Dent. 2012;2012:1-2.

10. Ministério da Saúde (BR). Portaria $n^{0} 2528$ de 19 de outubro de 2006. Aprova a Política Nacional de Saúde da Pessoa Idosa. Brasília: Ministério da Saúde; 2006.

11. World Health Organization - WHO. Oral health surveys: basic methods. $4^{\text {Th }}$ ed. Geneva: RH/EPID; 1997.

12. Moreira RS, Nico LS, Tomita NE. Oral health conditions among the elderly in Southeastern São Paulo State. J Appl Oral Sci. 2009;17(3):170-8.

13. Gundala R, Chava VK. Effect of lifestyle, education and socioeconomic status on periodontal health. Contemp Clin Dent. 2010;1(1):23-6.

14. Johansson CS. Periodontitis and coronary artery disease: studies on the association between periodontitis and coronary artery disease [these]. Linköping: Division of Cardiovascular Medicine Department of Medical and Health Sciences Linköping University; 2013

15. Johansson CS, Richter A, Lundström A, Torstensson $\mathrm{H}$, Ravald N. Periodontal conditions in patients with coronary heart disease: a case-control study. J Clin Periodontol. 2008;35(3):199-205.

16. Sociedade Brasileira de Diabetes. Estatísticas do diabetes no Brasil e no mundo [Internet]. São Paulo: 
SBD [cited 2010 Nov 10]. Available from: http://www. diabetes.org.br/Diabetes/diabet_set.htm

17. Bascones-Martinez A, Matesanz-Perez P, EscribanoBermejo M, Gonzá-lez-Moles MA, Bascones-Ilundain J, Meurman JH. Periodontal disease and diabetesReview of the literature. Med Oral Patol Oral Cir Bucal. 2011;16(6):e722-9.

18. Santana TD, Costa FO, Zenóbio EG, Soares RV, Santana TC. Impacto da doença periodontal na qualidade de vida de indivíduos diabéticos dentados. Cad Saúde Pública. 2007;23(3):637-44.

19. Lopes FF, Loureiro FHF, Pereira AFV, Pereira ALA, Alves CMC. Associação entre osteoporose e doença periodontal em mulheres na pós-menopausa. Rev Bras Ginecol Obstet. 2008;30(8):379-83.

20. Esfahanian V, Shamami MS, Shamami MS. Relationship between osteoporosis and periodontal disease: review of the literature. J Dent (Tehran). 2012;9(4):356-64.

21. Saintrain MVL, Vieira LJES. Saúde bucal do idoso: abordagem interdisciplinar. Ciênc Saúde Coletiva. 2008;13(4):1127-32.

22. Queiroz CM, Resende CP, Molena CCL, Denardin OVP, Rapoport A. Avaliação da condição periodontal no idoso. Rev Bras Cir Cabeça Pescoço. 2008;37(3): $156-9$.

23. Cesar Neto JB, Rosa EF, Pannuti CM, Romito GA. Smoking and periodontal tissues: a review. Braz Oral Res [online]. 2012;26(Spec No 1):25-31.

24. Pejčić A, Obradović R, Kesić L, Kojović D. Smoking and periodontal disease: a review. Med and Biol. 2007;14(2):53-9.

25. Ferreira RC, Magalhães CS, RochaES, Schwambach CW, Moreira AN. Saúde bucal de idosos residentes em instituições de longa permanência de Belo Horizonte, Minas Gerais, Brasil. Cad Saúde Pública. 2009; 25(11):2375-85.

26. Kaye EK, Valencia A, Baba N, et al. Tooth loss and periodontal disease predict poor cognitive function in older men. J Am Geriatr Soc. 2010;58(4):713-8.

27. Sriyono NW. Correlation of age, attitude, and dental care behavior with the oral health status of institutionalized elderly in Yogyakarta, Indonesia. Hong Kong Dent J. 2005;2:30-4.

28. Lindhe J, Karring T, Araújo M. Anatomia dos tecidos periodontais. In: Lindhe J, Lang NP, Karring T. Tratado de periodontia clínica e implantodontia oral. São Paulo: Guanabara Koogan; 2010.

29. Hopcraft MS, Morgan MV, Satur JG, Wright FA, Darby IB. Oral hygiene and periodontal disease in Victorian nursing homes. Gerodontology. 2012;29(2):e220-8.

30. Martins AMEBL, Haikal DS, Pereira SM, Barreto SM. Uso de serviços odontológicos por rotina entre idosos brasileiros: Projeto SB Brasil. Cad Saúde Pública. 2008;24(7):1651-66.

31. Ministério da Saúde (BR). Diretrizes da Política Nacional de Saúde Bucal [Internet]. Brasília: Ministério da Saúde; 2004 [cited 2012 Feb 11]. Available from: http://dab.saude.gov.br/CNSB/brasil_sorridente.php.

\section{Endereço para correspondência:}

Maria Vieira de Lima Saintrain

Universidade de Fortaleza

Mestrado de Saúde Coletiva

Av. Washington Soares, 1321

Bairro: Edson Queiroz

CEP: 60.811-905 - Fortaleza - CE - Brasil

E-mail: mvlsaintrain@yahoo.com.br 